\title{
PENERAPAN MODEL PEMBELAJARAN NUMBER HEAD TOGETHER (NHT) UNTUK PENGEMBANGAN KOSAKATA ENGLISH FOR BUSINESS
}

\author{
Iksan \\ Sekolah Tinggi Agama Islam Al-Gazali Bone, Indonesia \\ e-mail: ikhsan_kartika@yahoo.com
}

\begin{abstract}
This research is a classroom action research that aims to improve the students' ability in recognizing, understanding, and using vocabularies in English for Business, and enhance the quality of learning process from teacher or students view through the implementation of NHT. The source of research data was from the learning process of English subject to the students X grade of SMA Negeri 18 Makassar. The result showed that the activities of students become very pleased and increase their learning vocabulary English for Business by applying NHT in the class.
\end{abstract}

Keywords: Number Head Together (NHT), Students' Learning Outcome, Vocabulary of English for Business

\section{Pendahuluan}

Bahasa memiliki peranan sentral dalam perkembangan intelektual, sosial, dan emosional peserta didik dan merupakan penunjang keberhasilan dalam mempelajari semua bidang studi. Bahasa juga membantu peserta didik untuk mampu menggunakan gagasan dan perasaan, berpartisipasi dalam masyarakat, menemukan serta menggunakan kemampuan analitis dan imajinatif yang ada dalam dirinya. Maka dari itu, sekolah sebagai institusi formal mempunyai beberapa bidang studi bahasa baik bahasa Indonesia maupun bahasa asing yang wajib diajarkan guna mengembangkan kemampuan berkomunikasi seseorang secara tulis maupun lisan.

Permasalahan yang ada dalam dunia pendidikan formal senantiasa bertambah dari tahun ke tahun, karena pendidikan di tuntut selalu mengalami kemajuan dari berbagai segi. Salah satu segi penting dalam hal ini adalah proses belajar mengajar. Di dalam proses belajar mengajar ini terdapat berbagai macam kegiatan di antaranya adalah cara menyampaikan pelajaran. Di dalam proses belajar mengajar khususnya Bahasa Inggris berbasis ESP (English for Specific Purposes) atau Bahasa Inggris untuk tujuan tertentu dalam hal ini English for Business masih menggunakan metode pembelajaran konvensional, sehingga siswa hanya mendengarkan guru menerangkan materi dan siswa tidak ikut aktif dalam proses pembelajaran. Kelemahan dari pembelajaran ini adalah peserta didik cenderung pasif, pengaturan kecepatan cara klasikal di tentukan oleh pengajar, 
kurang cocok untuk pembentukan keterampilan dan sikap, dan cenderung menempatkan pengajar sebagai otoritas terakhir. ${ }^{1}$ Tujuan pendidikan tidak akan tercapai apabila pengajaran yang dilakukan oleh guru di sekolah masih berpusat pada guru (pembelajaran konvensional) karena dengan pembelajaran ini akan menjadikan siswa menjadi pasif dan tidak akan berkembang. ${ }^{2}$ Hal ini selanjutnya akan berdampak pada rendahnya hasil belajar siswa.

Fenomena di atas terjadi secara merata dan berdampak pula pada SMA Negeri 18 Makassar kelas X pada semester ganjil tahun ajaran 2017/2018, dimana proses pembelajaran berpusat dan didominasi oleh guru (teacher centre). Dalam pembelajaran kosakata bahasa Inggris berbasis English for Business, guru kurang memperhatikan strategi yang tepat untuk pembelajaran bahasa Inggris beraliran ESP ini sehingga aktivitas belajar siswa di kelas tersebut sangat monoton dimana pembelajaran berpusat pada guru. Hal ini mengakibatkan kurangnya respon positif siswa dalam belajar kosakata bahasa Inggris berbasis English for Business yang berdampak pada motivasi dan minat siswa dalam belajar bahasa Inggris.

Agar siswa menjadi aktif dan termotivasi dalam proses kosakata bahasa Inggris berbasis English for Business maka seorang guru harus mampu memilih model, strategi atau pendekatan pembelajaran yang cocok dengan keadaan kelasnya yang bertujuan untuk meningkatkan hasil belajar bahasa Inggris siswa.Untuk mencapai tujuan tersebut, tidak bisa terlepas dari model pembelajaran yang merupakan bagian integral dari proses pembelajaran. Dalam kurikulum 2013 guru diberi kebebasan untuk memanfaatkan berbagai model pembelajaran yang dapat membangkitkan minat, perhatian, dan kreativitas peserta didik. Gagne menyatakan bahwa fase dalam kegiatan membelajarkan adalah sebagai berikut: fase motivasi, fase menaruh perhatian (attention, alertness), fase pengolahan, fase umpan balik (feedback, reinforcement). ${ }^{3}$ Berdasarkan penjelasan diatas dapat disimpulkan bahwa pembelajaran bermodel perlu dikembangkan. Model yang digunakan haruslah yang menarik dan sesuai dengan karakteristik peserta didik sehingga dapat memotivasi untuk belajar. Salah satu model pembelajaran yang dapat digunakan adalah pembelajaran Number Head Together.

Numbered Heads Together (NHT) adalah salah satu tipe pembelajaran kooperatif, sehingga semua prinsip dan konsep pembelajaran kooperatif ada pada NHT ini. Dalam model NHT ada hubungan saling ketergantungan positif antar siswa, ada tanggung jawab perseorangan, serta ada komunikasi antar anggota kelompok. Pelibatan siswa secara kolaboratif dalam kelompok untuk mencapai tujuan bersama memungkinkan NHT dapat meningkatkan hasil belajar siswa.

1 Hasibuan, Malayu S.P., Manajemen Sumber Daya Manusia (Jakarta: Bumi Aksara, 2002).

2 Asmaningtias, Yeni Tri., Kemapuan Matematika Laki-Laki dan Perempuan (Malang:UIN Malang, 2010)..

3 Majid, Abdul., Perencanaan Pembelajaran (Bandung : Remaja Rosdakarya, 2008). h.69 
Model ini sangat sesuai dengan ciri khas pokok bahasan kosakata (vocabulary), dimana dalam pokok bahasan ini siswa dituntut melakukan langkah-langkah dalam pembelajaran kosakata bahasa Inggris berbasis English for Business.

Berdasarkan uraian yang telah dipaparkan diatas, peneliti memandang perlunya dilakukan penelitian yang berbasis model NHT dengan judul "Penerapan Model Pembelajaran NHT untuk Pengembangan Kosakata English for Business".

\section{Metode Penelitian}

Sebelum melakukan penelitian tindakan kelas, peneliti terlebih dahulu melakukan observasi awal. Observasi awal dilakukan untuk mengetahui kondisi real kelas yang terlaksana bulan Juli 2017. Selama kegiatan berlangsung, peneliti mengamati keaktifan dan pemahaman materi peserta didik kelas $X$ SMA Negeri 18 Makassar. Peneliti adalah guru bahasa Inggris di sekolah tersebut, namun tidak mengajar pada program peminatan English for Business. Dari hasil observasi yang dilakukan peneliti, peserta didik masih banyak yang diam dan kurang aktif dalam mengikuti pembelajaran. Salah satu penyebabnya adalah model pembelajaran yang digunakan membuat peserta didik merasa bosan dan tidak tertarik terhadap mata pelajaran yang disampaikan guru.

Observasi kedua dilakukan pada bulan yang sama namun pada tanggal yang berbeda, yaitu tanggal 12 Juli 2017. Observasi ini dilakukan untuk menyepakati bahwa tindakan akan dilakukan pada kelas X SMA Negeri 18 Makassar karena keterlibatan peserta didik dalam proses pembelajaran masih belum maksimal, dari hasil observasi peneliti mendapat informasi tentang kondisi di kelas pada saat proses pembelajaran berlangsung guru cenderung lebih banyak menggunakan model konvensional sehingga perhatian dan keaktifan peserta didik belum optimal, maka dapat disimpulkan keaktifan dan interaksi peserta didik pada proses pembelajaran masih rendah. Dari permasalahan tersebut maka peneliti melakukan penelitian tindakan kelas untuk meningkatkan keaktifan dan hasil belajar peserta didik dengan menggunakan model pembelajaran kooperatif tipe NHT. Guru pada program peminatan menyambut baik penelitian ini.

Tindakan penelitian ini dilaksanakan pada tanggal 17 Juli sampai 9 September 2017. Penelitian ini dilaksanakan dalam dua siklus. Masing-masing siklus dilaksanakan dalam satu kali pertemuan, yaitu pembelajaran teori dengan alokasi waktu untuk satu kali pertemuan selama 2 x 45 menit.

Sementara itu dari data kuantitatif yang didapat oleh peneliti sebelum dilakukan penelitian tindakan kelas, kemampuan siswa kelas X dalam melafalkan dan mengetahui kosakata English for Business masih rendah. Nilai rata-rata yang diperoleh adalah 5,97 dan siswa yang telah mencapai tingkat ketuntasan belajarnya (dengan memperoleh nilai $\geq 6,5$ ) baru mencapai $34,8 \%$. 
Subjek dalam penelitian ini adalah siswa kelas kelas $\mathrm{X}$ SMA Negeri 18 Makassar semester ganjil tahun ajaran 2017/2018 pada program peminatan. Program peminatan merupakan program pilihan siswa per kelas yang dilaksanakan di luar jam belajar regular. Jumlah kelas X yang mengikuti program peminatan ini sebanyak 30 orang siswa (12 laki-laki dan 18 perempuan).

\section{Teknik Pengumpulan Data}

\section{Tes Hasil Belajar}

Pada penelitian ini terdapat dua tes yang diberikan kepada siswa untuk mengetahui hasil belajar siswa, antara lain sebagai berikut:

\section{a. Pretest}

Digunakan untuk mengukur kemampuan awal dan hasil belajar siswa sebelum dilakukannya tindakan. Tes awal merupakan tes yang dilaksanakan sebelum bahan pelajaran diberikan kepada siswa dengan tujuan untuk mengetahui sejauh manakah materi pelajaran yang diajarkan telah dapat dikuasai oleh siswa.

\section{b. Posttest}

Posttest diberikan setelah penelitian tindakan dilakukan agar diketahui hasil belajar siswa dan keberhasilan tindakan. Posttest merupakan tes yang dilaksanakan dengan tujuan untuk mengetahui apakah semua materi pelajaran yang tergolong penting sudah dikuasai dengan sebaik-baiknya oleh siswa.

2. Observasi

Observasi merupakan metode pengumpulan data melalui pengamatan dan pencatatan perilaku subyek penelitian yang dilakukan secara sistematik. ${ }^{4}$ Observasi digunakan untuk mengumpulkan data keaktifan/aktivitas siswa pada saat proses pembelajaran kosakata bahasa Inggris bisnis.

\section{Dokumentasi}

Dokumen digunakan untuk memperkuat bukti penelitian. Dokumentasi yang digunakan dalam penelitian ini berupa nilai siswa, pedoman observasi, dan dokumen pendukung saat proses belajar mengajar di kelas.

\section{Instrumen Penelitian}

Instrumen penelitian adalah alat yang digunakan untuk mengumpulkan data pada saat penelitian, instrumen penelitian yang digunakan oleh peneliti adalah:

1. Tes Hasil Belajar

Tes berisi pertanyaan-pertanyaan mengenai materi yang telah disampaikan yang harus dijawab oleh siswa, jawaban di dalam tes dapat berupa tulisan, bentuk dari tes yang digunakan ada lima. Pertanyaan pertanyaan dalam tes bertujuan untuk mengukur hasil belajar siswa. 


\section{Lembar Observasi}

Lembar observasi adalah alat untuk menilai aktivitas siswa pada saat proses embelajaran berlangsung. Lembar observasi mencakup data mengenai keaktifan siswa yaitu mencakup aktivitas siswa selama proses pembelajaran berlangsung. Kisi-kisi lembar observasi keaktifan siswa meliputi komponen Disiplin, Motivasi, Kesiapan belajar, Pemusatan perhatian, Antusiasme, Tanyajawab, Kerja individual, Kerja kelompok, Mengerjakan tugas, Konstruktivisme, Penampilan, Sosialisasi, Pengendalian diri, Percaya diri, dan Tanggung jawab.

\section{Teknik Analisis Data}

Dalam penelitian diharapkan memperoleh hasil yang didapat dari alat penilaian yang digunakan berupa tes. Nana Sudjana mengemukakan bahwa, "proses mengubah skor mentah menjadi skor masak dengan menggunakan teknik statistika disebut pengolahan data". 5 Peneliti lalu mengubahnya menjadi skor masak agar skor tersebut dapat memiliki makna dengan cara diolah menjadi data yang berarti untuk menentukan hasil belajar siswa. Penelitian ini dikatakan berhasil jika hasil belajar seluruh siswa dari posttest $100 \%$ lulus atau memiliki peningkatan dibandingkan dengan nilai pretest dari seluruh siswa.

\section{Indikator Keberhasilan}

Untuk menentukan ketuntasan belajar siswa (individual) dapat dihitung dengan menggunakan persamaan sebagai berikut : ${ }^{6}$

$$
\mathrm{KB}=\frac{\underline{\mathrm{T}}}{\mathrm{T}_{1}} \times 100 \%
$$

Ket: $K B=$ ketuntasan belajar, $T=$ jumlah skor yang diperoleh siswa, $T_{l}=$ skor total

Ketuntasan belajar klasikal siswa dihitung dengan menggunakan rumus:

$$
\text { Ketuntasan Klasikal }=\quad \frac{\text { Jumlah Siswa yang mendapat Nilai 59 }}{\text { Total Jumlah Siswa }} \quad \text { X 100\% }
$$

Mengadopsi pendapat Saadah \& Ridwan tentang kriteria keberhasilan pembelajaran yang sesuai dengan tujuan penelitian tindakan kelas ini dengan perolehan skor dalam persentase $(\%)$ sebagai berikut: ${ }^{7}$

a. Tingkat keaktifan/aktivitas siswa rata-rata selama proses pembelajaran dalam persentase: $\geq 80$ (sangat baik), $60-79$ (baik), 40 - 59 (cukup), $20-39$ (kurang), $<20$ (sangat kurang).

5 Nana Sudjana, Dasar-Dasar Proses Belajar Mengajar (Bandung: Sinar Baru Algesindo, 2005).

6 Trianto, Model Pembelajaran Terpadu Konsep, Strategi dan Implementasinya dalam Kurikulum Tingkat Satuan Pendidikan (KTSP) ( Jakarta : Bumi Aksara, 2011).

7 Ridwan \& Saadah, Penelitian Tindakan Kelas (Bandung, 2002) 
b. Tingkat keberhasilan belajar siswa dalam persentase: $\geq 80$ (sangat tinggi), 60 - 79 (tinggi), 40 - 59 (sedang), 20 - 39 (rendah), < 20 (sangat rendah).

\section{Pembahasan}

\section{Data Keaktifan pada Silus I}

Pada siklus I setelah digunakan Model Pembelajaran kooperatif tipe NHT dapat diketahui bahwa aktifitas belajar peserta didik pada pembelajaran kosakata English for Business yaitu komponen proses aktivitas pembelajaran berada pada kategori Cukup dan kategori Baik dengan jumlah presentase rata-rata 74,67\% yang meliputi komponen disiplin, kesiapan belajar, pemusatan perhatian, antusiasme, motivasi, tanya-jawab, kerja individual, kerja kelompok, mengerjakan tugas, konstruktivisme, penampilan, sosialisasi, pengendalian diri, percaya diri, dan tanggung jawab. Pada siklus I, Peserta didik bisa mengikuti jalannya pembelajaran dengan menggunakan pembelajaran kooperatif tipe NHT walaupun dalam pelaksanaannya belum maksimal dan terdapat beberapa kendala. Belum semua peserta didik dapat berperan aktif selama proses pembelajaran, masih ada beberapa peserta didik yang kurang aktif dan belum optimal dalam melaksanakan kerja kelompok, kesiapan belajar, pemusatan perhatian, antusiasme, dan motivasi. Beberapa materi kosakata English for Business pun masih terasa asing bagi siswa sebab ketika siswa mencari terjemahan kosakata-kosakata tersebut di dalam kamus bahasa Inggris, mereka masih belum menemukannya. Peneliti berpendapat bahwa proses ini adalah lumrah karena kosakata tersebut memang bukan kosakata umum yang bisa didapatkan didalam kamus bahasa Inggris yang umum tetapi pada kamus tertentu saja. Suasana proses pembelajaran belum kondusif, peserta didik masih merasa canggung dan kurang nyaman dalam kelompok diskusinya. Selain itu, beberapa peserta didik telah berperan aktif selama proses pembelajaran berupa tugas individu. Walaupun keaktifan dari beberapa peserta didik telah terbentuk namun keaktifan peserta didik tersebut perlu untuk ditingkatkan.

\section{Data Keaktifan pada Siklus II}

Pada siklus II, dengan model pembelajaran yang sama yaitu model pembelajaran kooperatif tipe NHT proses pembelajaran jauh lebih baik dibandingkan pada siklus I, siswa sudah mulai terbiasa dengan metode pembelajaran kooperatif tipe ini. Siswa tampak bersemangat dan kegiatan diskusi antar kelompok berjalan lancar. Secara keseluruhan peningkatan keaktifan siswa pada siklus II menunjukkan peningkatan dan tergolong tinggi. Aktifitas belajar peserta didik di kelas pada pembelajaran kosakata English for Business khususnya pada komponen-komponen proses aktivitas pembelajaran berada pada kategori Sangat Baik dan kategori Baik dengan jumlah presentase rata-rata $84 \%$ yang meliputi komponen disiplin, kesiapan belajar, pemusatan perhatian, antusiasme, 
motivasi, tanya-jawab, kerja individual, kerja kelompok, mengerjakan tugas, konstruktivisme, penampilan, sosialisasi, pengendalian diri, percaya diri, dan tanggung jawab. Komponen aktifitas belajar siswa yang meliputi kesiapan belajar, pemusatan perhatian, antusiasme, motivasi mengalami peningkatan dari kategori Cukup ke kategori Baik. Sedangkan komponen aktifitas belajar siswa yang meliputi individual, kerja kelompok, mengerjakan tugas, konstruktivisme mengalami peningkatan signifikan dari kategori Baik ke kategori Sangat Baik. Pada siklus II ini, peserta didik lebih meningkat secara signifikan dimana siswa telah diberikan kosakata oleh guru bahasa Inggris agar mereka tidak kesulitan dalam mempelajari kosakata tersebut. Proses pemebelajaran kosakata English for Business mulai dari pengenalan kata, pemahaman arti kata, hingga penggunaan kata dalam kalimat telah berjalan dengan lebih baik dari sebelumnyaPeningkatan aktivitas peserta didik pada pembelajaran kosakata English for Business dari siklus I ke siklus II ini dikarenakan peserta didik sudah merasa senang dan bersemangat ketika mengikuti proses pembelajaran dengan menggunakan model Pembelajaran kooperatif tipe NHT, peserta didik sudah bisa membaur dan merasa nyaman dalam kelompok diskusinya serta suasana proses pembelajaran sudah kondusif.

\section{Data Rata-Rata Hasil Belajar Siswa}

Hasil belajar siswa pada pembelajaran Kosakata English for Business melalui penerapan model NHT pada Siklus I berada pada kategori Tinggi namun hal tersebut belum membuat peneliti menyimpulkan bahwa penerapan kosakata telah mencapai hasil yang baik. Melalui hasil rata-rata belajar pada siklus II, maka peneliti berpendapat bahwa terdapat peningkatan yang cukup baik di dalamnya di mana terdapat regenerasi angka. Rata-rata hasil belajar siswa adalah sebesar 62.00 pada siklus I dan 67.52 pada siklus II, maka dapat disimpulkan bahwa terdapat peningkatan angka pada siklus II walaupun kategorinya berada pada level yang sama yaitu kategori Tinggi. Namun demikian, ketuntasan belajar siswa pada siklus I ke siklus II mengalami peningkatan angka yang signifikan yaitu 52,17 ke 86,96 di mana kategori pada siklus I bergerak ke siklus II yaitu dari kategori Sedang ke kategori Tinggi. Dengan demikian, peneliti berkesimpulan bahwa hasil belajar siswa mengalami peningkatan pada rata-rata hasil belajar yang pada akhirnya ketuntasan belajar pun mengalami peningkatan yang signifikan. Pemetaan analisis hipotesa dapat dilihat pada table 3.1 di bawah ini:

Tabel 3.1: Pemetaan Analisis Hipotesa Pada Pembelajaran Kosakata English for Business melalui penerapan model Number Head Together (NHT) pada Siklus I dan Siklus II. ${ }^{8}$

8 Nartalina Nina, Upaya Meningkatkan Kemampuan Siswa Dalam Menulis Kalimat Fungsional Sederhana Dalam Bentuk Lampau Pada Pembelajaran Writing Melalui Tehnik Write-Pair-Square dan Tehnik Two Stay Two Stray 


\begin{tabular}{llccccc}
\hline No. & \multicolumn{1}{c}{$\begin{array}{l}\text { Indikator } \\
\text { Penilaian }\end{array}$} & $\begin{array}{c}\text { Sebelum } \\
\text { PTK } \\
(\%)\end{array}$ & $\begin{array}{c}\text { Hasil } \\
\text { Siklus I } \\
(\%)\end{array}$ & $\begin{array}{c}\text { Ketera- } \\
\text { ngan }\end{array}$ & $\begin{array}{c}\text { Hasil } \\
\text { Siklus II } \\
(\%)\end{array}$ & $\begin{array}{c}\text { Ketera- } \\
\text { ngan }\end{array}$ \\
\hline 1. & $\begin{array}{l}\text { Keaktifan/Aktifitas } \\
\text { Siswa }\end{array}$ & - & 74,67 & Baik & 84,0 & $\begin{array}{c}\text { Sangat } \\
\text { Baik }\end{array}$ \\
& $\begin{array}{l}\text { Rata-rata Nilai } \\
\text { 2. }\end{array}$ & 59,7 & 62 & Tinggi & 67,5 & Tinggi \\
& $\begin{array}{l}\text { Hasil Belajar } \\
\text { Ketuntasan }\end{array}$ & 34,8 & 52,17 & Sedang & 86,9 & $\begin{array}{c}\text { Sangat } \\
\text { Tinggi }\end{array}$ \\
\hline
\end{tabular}

Pada table 3.1, dapat disimpulkan bahwa pembelajaran Kosakata English for Business melalui penerapan model NHT mengalami peningkatan pada aktifitas, rata-rata hasil belajar, dan ketuntasan belajar siswa.

Berdasarkan hasil pengamatan yang dilakukan peneliti sejak awal semester kedua tahun ajaran 2017/2018 di kelas X, sebelum PTK nilai keaktifan siswa pada saat proses pembelajaran kosakata English for Business adalah 60\% (cukup). Hal itu dibuktikan dengan kurang antusiasnya siswa pada pembelajaran tersebut dikarenakan bahan ajar vocabulary yang cenderung kaku dan sangat terikat pada kaidah bahasa. Disamping itu model dan tehnik pembelajaran yang diterapkan guru tampaknya sudah sangat dihafal oleh siswa sehingga siswa kurang merasakan tantangan. Setelah dilakukan PTK hasil observasi menunjukkan perubahan yang sangat signifikan pada aktifitas belajar siswa yaitu meningkat menjadi sangat baik $(74,67 \%)$ pada siklus I dan (84\%) pada siklus II.

Peningkatan rata-rata hasil belajar yang melonjak dari katagori cukup ke kategori tinggi yaitu pada siklus I meningkat dari (59,7\%) menjadi (62\%) dan pada siklus II naik lagi menjadi (67,5\%). Yang lebih menggembirakan lagi nilai rata-rata hasil belajar tersebut disertai pula dengan peningkatan pada ketuntasan belajar siswa yang memperoleh nilai $\geq 65$, yaitu dari $(34,8 \%)$ siswa yang telah tuntas sebelum PTK menjadi $(52,1 \%)$ siswa telah mencapai ketuntasan belajarnya pada siklus I dan meningkat lagi menjadi $(86,9 \%)$ pada siklus II.

Peningkatan keaktifan siswa dan rata-rata hasil belajar siswa tidak terlepas dari upaya guru yang terus meningkatkan dan mempertahankan keaktifannya dalam menjalankan tahapan-tahapan pembelajaran yang telah direncanakan sebelumnya yaitu dengan menggunakan model NHT sehingga proses pembelajaran kosakata English for Business mendapatkan hasil yang diinginkan

Kelas VII A SMPN 1 Tasikmalaya Tahun Pelajaran 2004/2005 (Tasikmalaya: Karya Tulis Ilmiah. Lomba Keberhasilan Guru Dalam Pembelajaran Tingkat Nasional Tahun 2006, 2005). 
peneliti. Hal ini sejalan dengan penelitian yang dilakukan oleh Mariaa Videlis yang menyatakan bahwa model pembelajaran Number Head Together dapat meningkatkan kemampuan kosakata Bahasa Inggris siswa khususnya pada ESP (English for Specific Purposes) yang terfokus pada kosakata di bidang bisnis dan perbankan. ${ }^{9}$ Penerapan model pembelajaran ini pada tingkat sekolah menengah atau kejuruan dapat memacu kemampuan siswa untuk mengenali, memahami, dan menggunakan kosakata di bidang bisnis dan perbankan sebagai pengetahuan awal mereka sebelum memasuki dunia ekonomi, perdagangan, dan perbankan.

Hasil Refleksi Siklus I:

Dari data yang diperoleh, peneliti menyimpulkan bahwa model pembelajaran kooperatif NHT mendapat hasil yang cukup baik dari sebelumnya. Tingkat keaktifan siswa dan hasil belajar siswa meningkat sehingga suasana belajar menjadi sangat kondusif. Namun sekalipun demikian, penulis tetap berpendapat bahwa penelitian harus berlanjut ke siklus II karena pada Siklus I kemampuan siswa mengenali kata, memahami makna kata, dan menggunakan kata tersebut masih terbatas pada pelafalan saja (nilai rata-rata mencapai 62 dengan dengan jumlah siswa yang telah tuntas mencapai 52,1\%), sementara ketika siswa diminta untuk mengenali kata, memahami makna kata, dan menggunakan kata-kata tersebut masih mengalami kesulitan.

Hasil Refleksi Siklus II:

Respon siswa terhadap diterapkannya model NHT sangat baik dengan ditandai tingkat keaktifan mereka selama proses pembelajaran kosakata English for Business berlangsung sangat baik. Hal itu tidak terlepas dari upaya dan aktivitas yang dijembatani oleh guru yang senantiasa sangat aktif. Suasana pembelajaran berlangsung sangat kondusif. Kondisi tersebut dibarengi dengan semakin meningkatnya rata-rata hasil belajar siswa. Kemampuan siswa dalam mengenali, memahami makna, dan menggunakan kata tersebut sangat baik sesuai dengan indikator pembelajaran yang sudah terpenuhi sehingga peneliti menyimpulkan tidak perlu lagi meneruskan penelitian ke siklus selanjutnya.

\section{Simpulan}

Penerapan model kooperatif tipe NHT pada pembelajaran kosakata English for Business program peminatan di kelas X SMA Negeri 18 Makassar semester ganjil tahun ajaran 2017-2018 dapat meningkatkan kemampuan siswa dalam mengenali kata, memahami makna kata, dan menggunakan kata tersebut

9 Videlis TE, Maria., Implementing Numbered Head Together Strategy to Improve the Vocabulary Ability for Business and Banking of the Tenth Graders of Marketing Department in SMKN 1 Lumajang (Malang: Tesis Universitas Negeri Malang, Program Studi Pendidikan Bahasa Inggris, 2011) 
dalam kalimat. Aktifitas atau keaktifan siswa menjadi menyenangkan dengan diterapkannya model pembelajaran tersebut.

Rata-rata hasil belajar siswa pun meningkat sangat baik setelah mempelajari kosakata English for Business dengan menerapkan model pembelajaran kooperatif tipe NHT (Numbered Heads Together) di kelas.

\section{Daftar Pustaka}

Asmaningtias, Yeni Tri. (2010). Kemampuan Matematika Laki-Laki dan Perempuan. UIN Malang.

Endang Mulyatiningsih. (2011). Riset Terapan Bidang Pendidikan dan Teknik. Yogyakarta: UNY Press.

Hasibuan , Malayu S.P. (2002). Manajemen Sumber Daya Manusia. Bumi Aksara. Jakarta.

Majid, Abdul. (2008). Perencanaan Pembelajaran. Bandung : Remaja Rosdakarya.

Nana Sudjana. (2005). Dasar-dasar Proses Belajar Mengajar. Bandung: Sinar Baru Algesindo.

Nartalina Nina. (2005). Upaya Meningkatkan Kemampuan Siswa dalam Menulis Kalimat Fungsional Sederhana dalam Bentuk Lampau pada Pembelajaran Writing. Karya Tulis Ilmiah. Lomba Keberhasilan Guru Dalam Pembelajaran Tingkat Nasional Tahun 2006: Tasikmalaya.

Ridwan \& Saadah. (2002). Penelitian Tindakan Kelas, Bandung.

Trianto. (2011). Model Pembelajaran Terpadu Konsep, Strategi dan Implementasinya dalam KTSP, Jakarta : Bumi Aksara.

Videlis TE, Maria. (2011). Implementing NHT Strategy to Improve the Vocabulary Ability for Business and Banking in SMKN 1 Lumajang. Tesis Universitas Negeri Malang. Program Studi Pendidikan Bahasa Inggris. 